\title{
Phase Transformations in High Alloy Cold Work Tool Steel
}

\author{
Roman Moravčík ${ }^{1, *}$ - Mária Štefániková1 - Roman Čička ${ }^{1}$ \\ L'ubomír Čaplovič1 1 - Karin Kocúrová1 1 Roman Šturm ${ }^{2}$ \\ ${ }^{1}$ Slovak University of Technology, Faculty of Materials Science and Technology, \\ Institute of Materials Science, Slovak Republic \\ 2 University of Ljubljana, Faculty of Mechanical Engineering, Slovenia
}

Phase transformations in the alloy tool steels have a crucial effect on the final properties of the steels. High alloy systems have different solidification conditions compared to construction steels. This paper deals with the phase evolution in high alloy tool steel in quasi-equilibrium state.

For analysis various methods such as differential thermal analysis, thermomagnetometry, light microscopy, scanning electron microscopy with energy dispersive analysis, X-ray diffraction analysis and dilatometry, were used. The analysed tool steel solidifies in three steps, and at lower temperatures secondary carbides are formed. Solidification begins at $1340{ }^{\circ} \mathrm{C}$ and is finished at $1208{ }^{\circ} \mathrm{C}$. The Curie temperature of this steel is approximately $780^{\circ} \mathrm{C}$.

Keywords: high alloy cold work tool steel, differential thermal analysis, scanning electron microscopy, X-ray diffraction analysis, dilatometry

\section{INTRODUCTION}

The development of high alloy tool steel is important due to the requirement for achieving better mechanical and physical properties. High alloy tool steels of ledeburitic type produced by powder metallurgy (PM) contain a high amount of carbon and alloying elements (mainly V, Cr, Mo) that form carbides [1] to [3]. Conventional methods preparation of ledeburitic type tool steels (mould casting and forming) was influenced by the liquation and segregation processes, which lead to anisotropy of microstructure and properties of high alloy tool steels with high carbon content. This fact limits the applications of these steels as performance tools [4] to [8]. To improve the properties of the ledeburitic tool steels, the technology of powder metallurgy can be used [7], [9] and [10].

The main advantages of PM high alloy tool steel are the homogeneous distribution and fine size of carbides and uniform chemical composition in cross section, thereby better properties are achieved [11] and [12]. Due to specific properties cold work tool steels have found a wide spectrum of applications in various industries at blanking, forming, shearing, punching and other applications [13] to [15].

Solidification of ledeburitic steel in quasiequilibrium conditions starts by austenite formation, then the formation of morphologically different $\mathrm{MC}$, $\mathrm{M}_{7} \mathrm{C}_{3}, \mathrm{M}_{6} \mathrm{C}$ and $\mathrm{M}_{23} \mathrm{C}_{6}$ carbides follows and the solidification is finished by eutectic reactions [16] to [19]. Some aspects of solidification of the high alloyed tool steels are described in [20].

In the case of rapidly solidified powders the solidification usually starts by the formation of solid solution with the dendritic, equiaxed and mixed types of solidification microstructures. However, due to recalescence effects also some amount of eutectic is usually formed [17] and [21] to [23]. For consolidation of powder the hot isostatic pressing (HIP) is often used. During HIP processing of rapidly solidified powder particles of high alloy tool steel significant changes in their microstructure and properties occur.

The differential thermal analysis technique/ thermomagnetometry is often used to determine the phase transitions including melting and solidification, liquation and formation of eutectics, recrystallization, dissolution and precipitation of new phases, solid-state transformation, and ferromagnetic to paramagnetic transition in a wide range of materials. Thermal analyses together with appropriate thermodynamic calculations can be used for analysis of such different materials as lead-free solders [24] and [25], carbon steels [26] and tool steels [27].

The aim of this work is the investigation of microstructure and phase transformations in selected high alloy cold work tool steel.

\section{EXPERIMENTAL PROCEDURE}

The investigated material was equivalent to high alloy cold work tool steel K390 Microclean. The chemical composition of steel is given in Table 1 . Higher vanadium content ensures good tool wear resistance and high hardness (about 66 HRC) after heat treatment.

Analysed high alloy cold work tool steel has an extremely high wear resistance, outstanding toughness and high compressive strength. [15] 
Table 1. Chemical composition of the investigated high alloy tool steel [wt. \%]

\begin{tabular}{ccccccc}
\hline $\mathrm{C}$ & $\mathrm{Cr}$ & $\mathrm{Mo}$ & $\mathrm{Si}$ & $\mathrm{V}$ & $\mathrm{W}$ & $\mathrm{Co}$ \\
\hline 2.47 & 4.15 & 3.62 & 0.41 & 8.94 & 1.13 & 2.02 \\
\hline
\end{tabular}

The compacts were prepared by HIP processing of the rapidly solidified powders. The parameters of processing were: $1100{ }^{\circ} \mathrm{C}, 100 \mathrm{MPa}$, during 90 minutes with protective gas Ar [28]. From compacts the samples for differential thermal analysis/ thermomagnetometry (DTA/TM) and dilatometry were prepared.

For simultaneous DTA and TM experiment the sample with total weight of $105 \mathrm{mg}$ was prepared and Netzsch STA 409 CD apparature with heating up to $1600{ }^{\circ} \mathrm{C}$ in $\mathrm{Ar}$ protective gas $(60 \mathrm{ml} / \mathrm{min}$.) was used. The heating and cooling rates for measurement were $10 \mathrm{~K} / \mathrm{min}$, during three measurement runs. The differences in DTA curves in the $2^{\text {nd }}$ run and in $3^{\text {rd }}$ run were negligible. This fact indicates that the sample was in quasi-equilibrium state after the 1 st run, so only the $2^{\text {nd }}$ run was further analyzed.

The microstructure of sample obtained from DTA experiment after standard metallographical procedure and chemical etching in 3\% Nital was observed using the Neophot 32 light microscope and Jeol JSM-7600F scanning electron microscope (SEM). The experimental technique of scanning electron microscopy and energy dispersive X-ray spectroscopy (EDS) was used to characterize the composition of the phases in the steel after DTA.

X-ray diffraction analysis was carried out by means of Philips PW 1810 X-ray diffractometer with Co anode $\left(\lambda \mathrm{CoK} \alpha=1.72091 \times 10^{-10} \mathrm{~m}\right)$ and secondary monochromator. The measuring step was $0.02^{\circ}$, for each step the holding time $10 \mathrm{~s}$ was used. For X-ray diffraction analysis the sample from DTA experiment was used.

To characterize the phase transformations in solid state the dilatometry analysis of bulk sample prepared from the HIP compact was used. The initial sample length was $9.58 \mathrm{~mm}$. The analysis was performed using Netszch $402 \mathrm{C}$ dilatometer in Ar protective gas with heating rates of $3 \mathrm{~K} / \mathrm{min}$, during two measurement runs. Also, in this case only the second run was further analysed.

\section{RESULTS}

\subsection{Microscopy}

The microstructure of the sample after DTA obtained by light microscopy is shown in Fig. 1. It can be seen that the microstructure is dendritic, however, each dendrite consists from carbide eutectic colonies. At the boundaries of eutectic colonies (Fig. 2) a secondary skeleton eutectic is present.

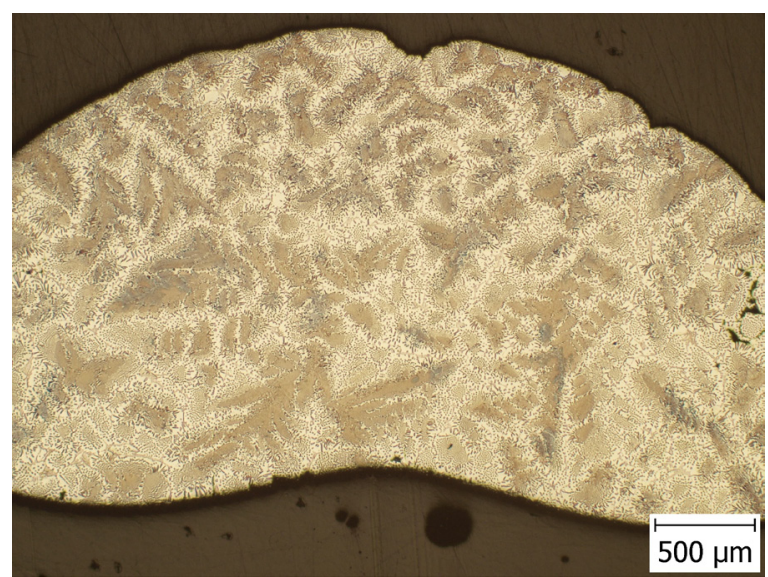

Fig. 1. Microstructure of the tool steel after DTA

For the more detailed interpretation of the microstructure SEM and EDS mapping techniques were used. On the base of element distribution (Fig. 3) it is shown that eutectic colonies contain the vanadium carbide and ferrite. The white carbides localized at the boundaries between eutectic colonies are on the base of molybdenum carbide. The eutectic colonies are rich in molybdenum and chromium. Cobalt and tungsten are distributed uniformly in all phases in material.

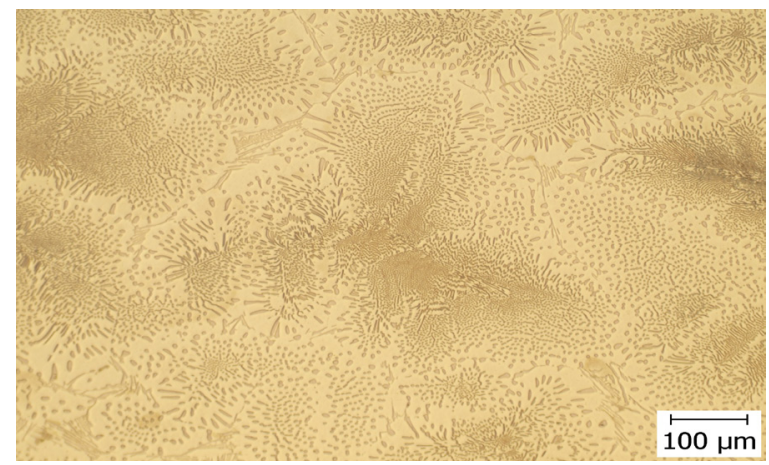

Fig. 2. Detail of the microstructure

\subsection{X-ray Diffraction Analysis}

X-ray diffraction pattern of sample after DTA is shown in Fig. 4. The following phases were observed: ferrite, $\mathrm{MC}$ carbide (vanadium type), $\mathrm{M}_{2} \mathrm{C}$ and $\mathrm{M}_{6} \mathrm{C}$ carbides (molybdenum types). Due to mixing of different substitutional atoms in carbide lattices the diffraction patterns of carbides are slightly shifted, compared to ICDD database [29] and [30]. 


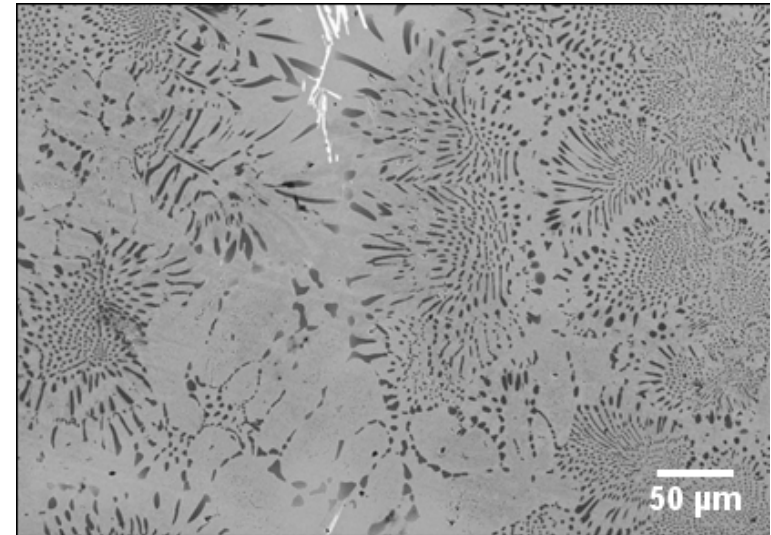

Mapped image (SEM)
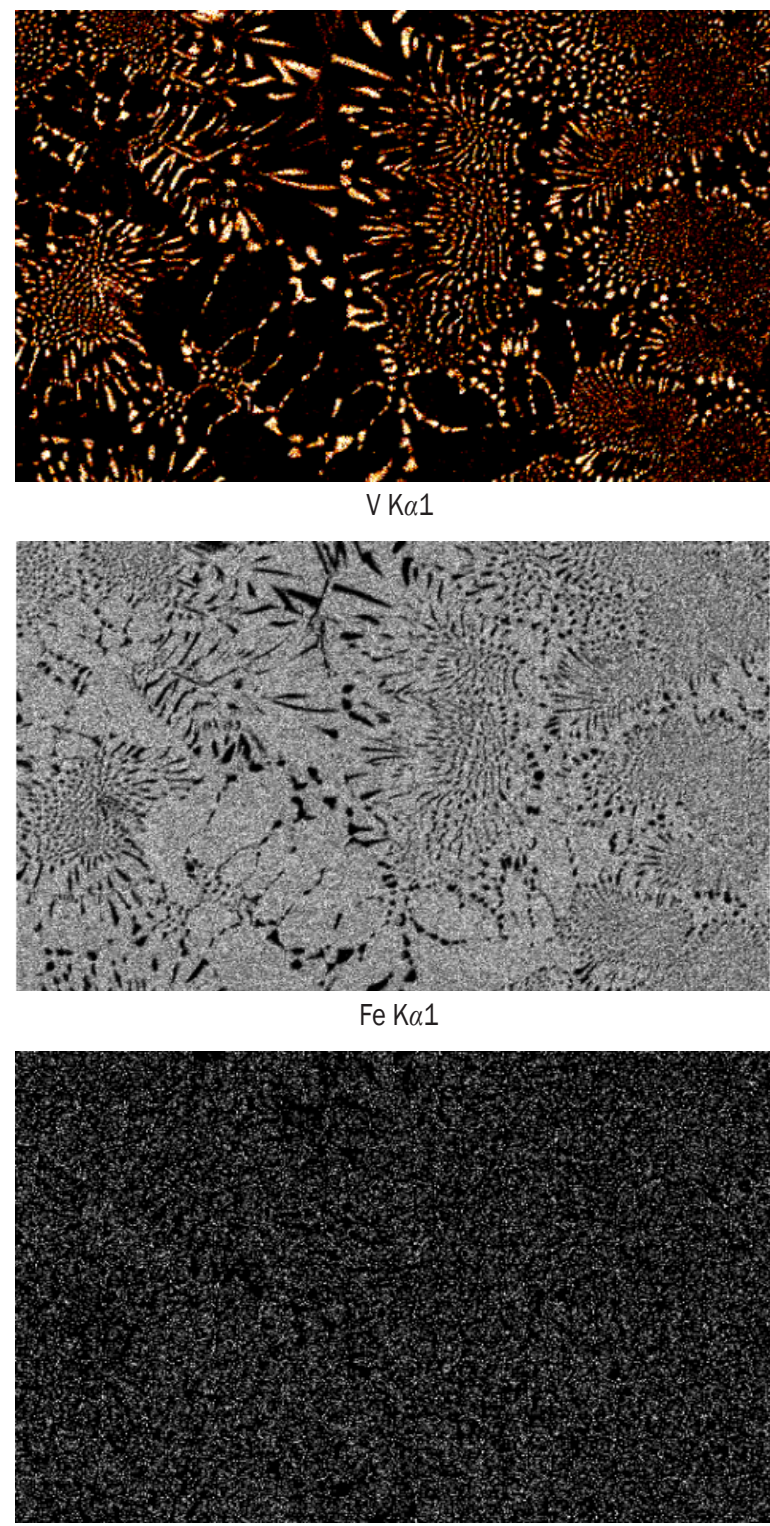

Co Ka1

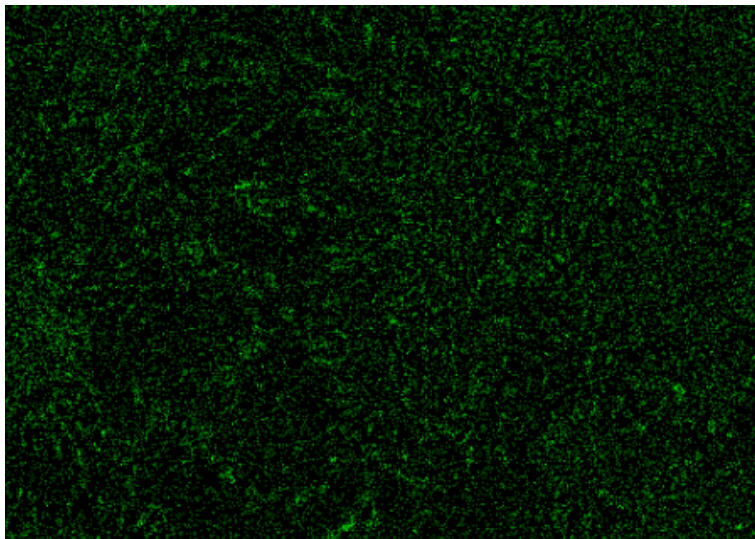

$\mathrm{C} \mathrm{K} \alpha 1,2$

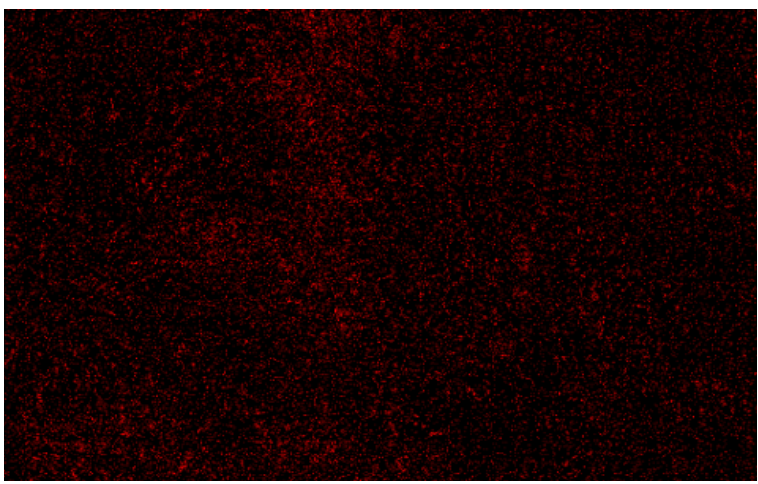

$\mathrm{CrK} \alpha 1$

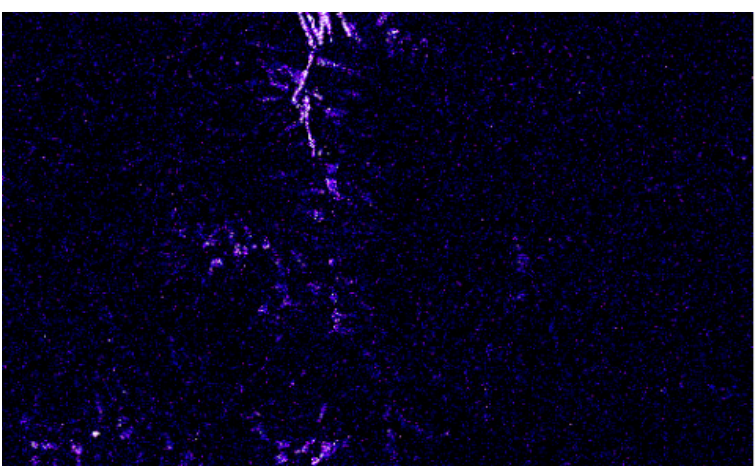

Mo La1

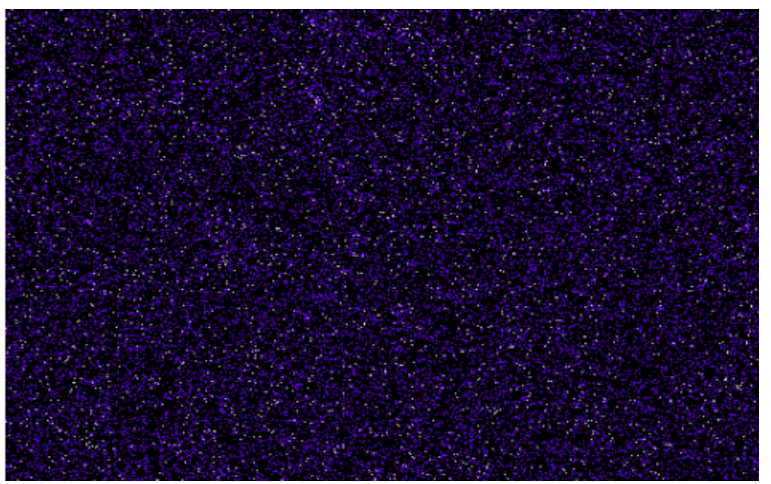

W L $\alpha 1$

Fig. 3. Element mapping of high alloy tool steel, showing distribution of $\mathrm{C}, \mathrm{V}, \mathrm{Cr}, \mathrm{Fe}, \mathrm{Mo}, \mathrm{Co}$ and $\mathrm{W}$ 


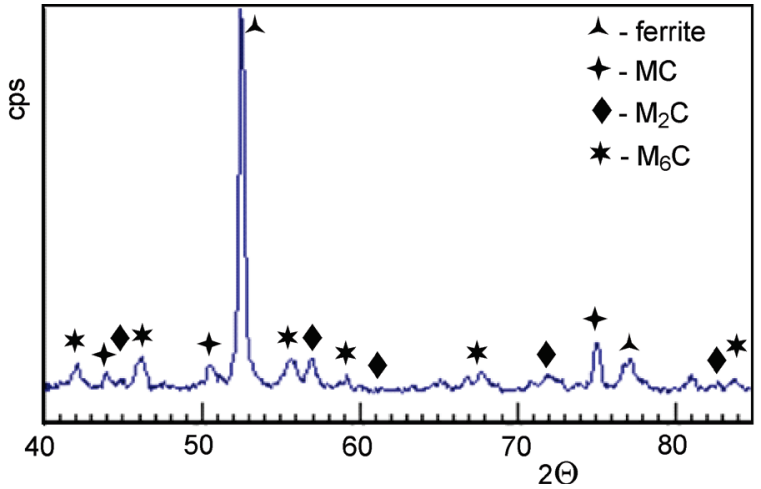

Fig. 4. X-ray diffraction pattern

\subsection{Differential Thermal Analysis and Thermomagnetometry}

Figs. 5 and 6 show DTA curves during heating and cooling of sample, respectively. The first peak in Fig.
5 represents the transformation from ferromagnetic to the paramagnetic state $\left(781{ }^{\circ} \mathrm{C}\right)$. The second endothermic peak (onset $856^{\circ} \mathrm{C}$ ) can be considered as the transformation of ferrite to austenite. Next peaks characterize the melting of the present phases. The melting begins at $1209^{\circ} \mathrm{C}$, and the end of melting the temperature is about $1389^{\circ} \mathrm{C}$.

\subsection{Dilatometry Analysis}

The dilatometry curve of analysed tool steel is shown in Fig. 7. The onset around temperature $660{ }^{\circ} \mathrm{C}$ is possibly caused by dissolving the secondary carbides in matrix. The steep decrease in length corresponding to the transformation of ferrite to austenite is present at about a temperature of $832{ }^{\circ} \mathrm{C}$.

DTA curve during cooling (Fig. 6) shows that solidification proceeds in three steps. Solidification probably begins by austenite formation from

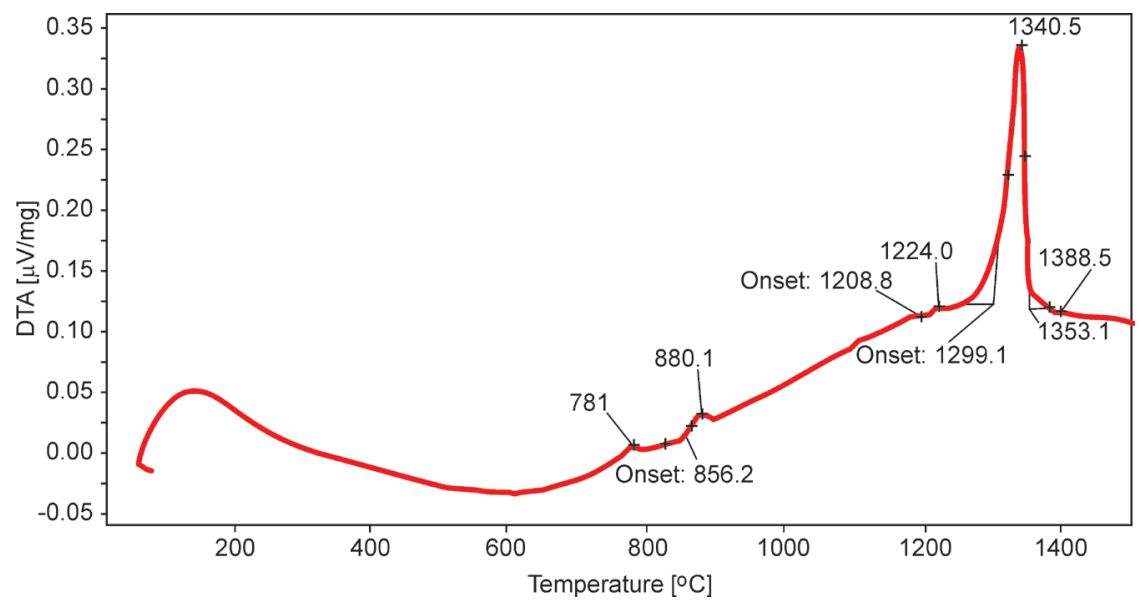

Fig. 5. DTA curve of the investigated high alloy tool steel during heating

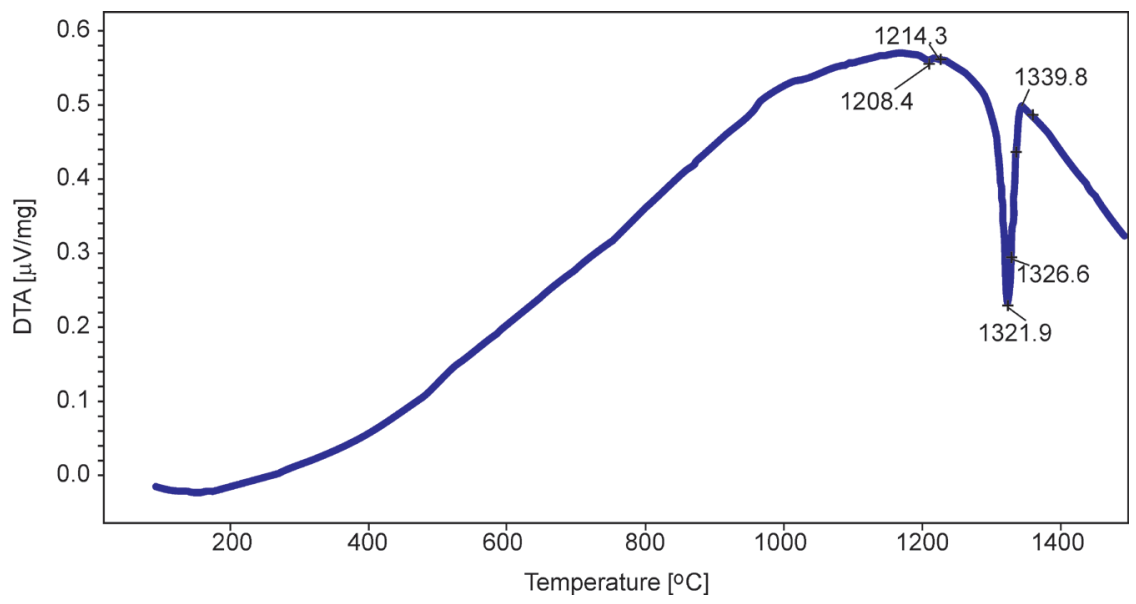

Fig. 6. DTA curve of the investigated high alloy tool steel during cooling 


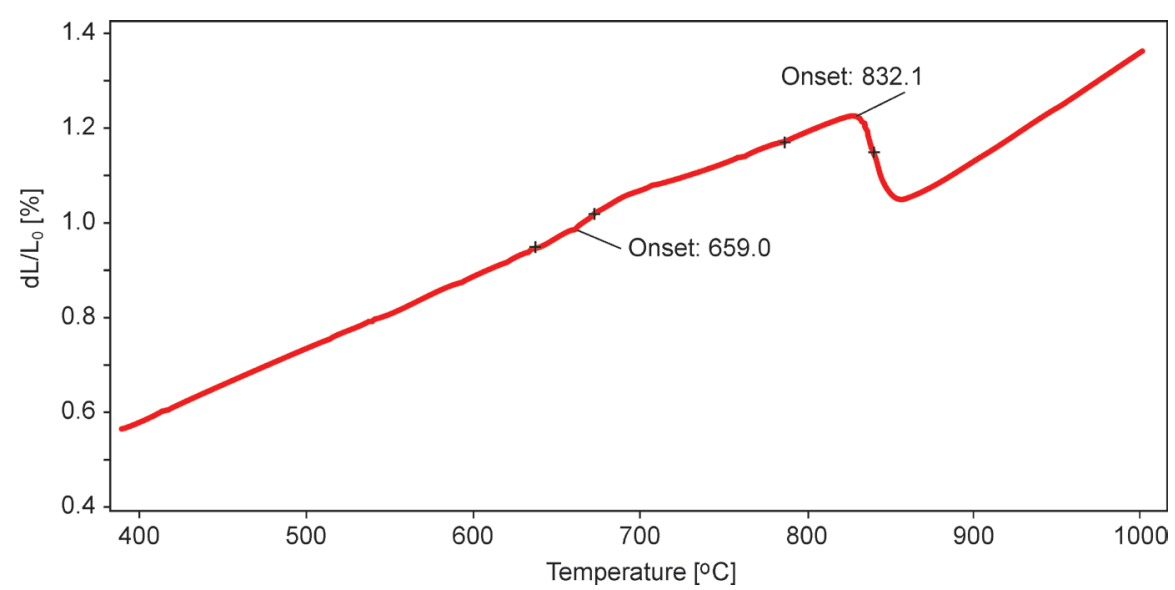

Fig. 7. Dilatometry curve of analysed tool steel during heating

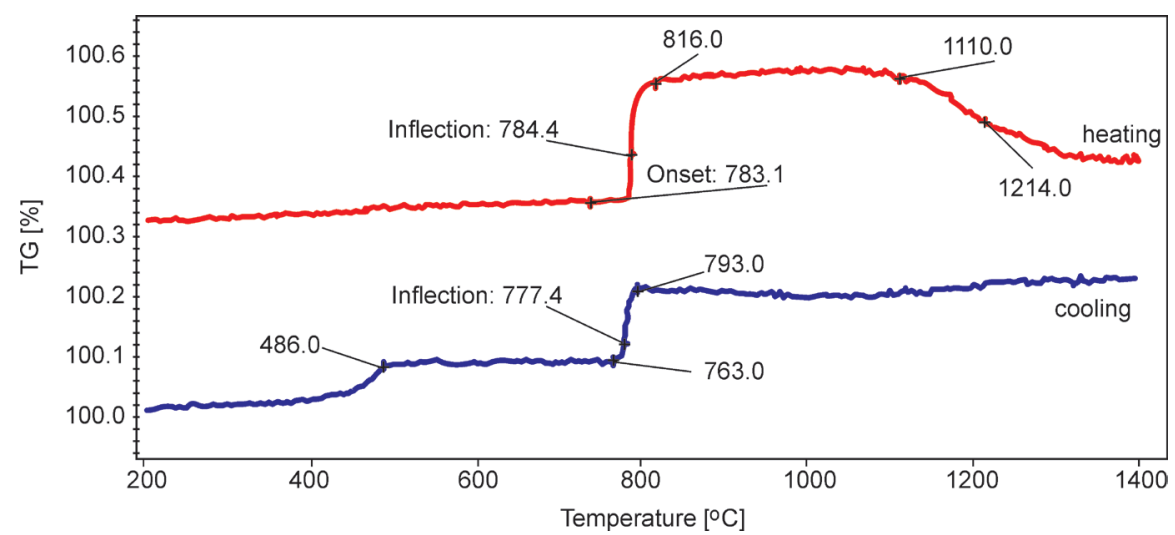

Fig. 8. Thermomagnetometry curves

undercooled melt at a temperature of $1340{ }^{\circ} \mathrm{C}$. The solidification continues with two eutectic reactions. During the first reaction probably eutectic with vanadium carbides is formed (at $1327{ }^{\circ} \mathrm{C}$ ). During the second reaction the eutectic with molybdenum carbides is formed (at $1214{ }^{\circ} \mathrm{C}$ ). The solidification is finished at a temperature of $1208{ }^{\circ} \mathrm{C}$. Fig. 8 shows the TM curve during heating and cooling of sample. About the temperature $780{ }^{\circ} \mathrm{C}$ the transformation from paramagnetic to ferromagnetic state is seen. During heating the curve slowly decreases from $1110^{\circ} \mathrm{C}$, probably due to dissolution of paramagnetic $\mathrm{MC}$ carbides. The cooling curve shows that at $486{ }^{\circ} \mathrm{C}$ also some secondary carbides form.

\section{DISCUSSION}

During heating of the high alloy cold work tool steel K390 Microclean the first secondary carbides start to dissolve in matrix at $660{ }^{\circ} \mathrm{C}$. The transition from ferromagnetic to paramagnetic state takes place at $781^{\circ} \mathrm{C}$ (determined by DTA) or $783^{\circ} \mathrm{C}$ (determined by TM). Then, the transformation of ferrite to austenite at a temperature of $856{ }^{\circ} \mathrm{C}$ (determined by DTA) occurs. This temperature is higher than the temperature of ferrite to austenite transition determined by dilatometry $\left(832{ }^{\circ} \mathrm{C}\right)$, probably due to higher heating rate at DTA measurements. Melting process of tool steel begins at temperature $1209{ }^{\circ} \mathrm{C}$ and continues in three steps. The first step is probably the melting of molybdenum carbide eutectics at $1209{ }^{\circ} \mathrm{C}$. They are localised on the boundary of eutectic colonies Melting of the material continues by melting of vanadium carbide eutectic colonies. Finally, melting finishes when the last amount of austenite is dissolved in the melt at temperature $1389^{\circ} \mathrm{C}$.

Also, solidification of the material proceeded in three steps. In undercooled melt the austenite grains grow at the temperature $1340{ }^{\circ} \mathrm{C}$. Next, solidification continues by the evolution of eutectic colonies based on the vanadium carbide (starts at $1327{ }^{\circ} \mathrm{C}$ ). Molybdenum is diffusing to the melt and in the 
last step of solidification the molybdenum carbide eutectics at the boundaries are formed. The cooling in solid state shows only two transitions in TM curve. The first change is the transition from paramagnetic to ferromagnetic state at $793{ }^{\circ} \mathrm{C}$ and the second one is the formation of the secondary carbides in the matrix at $486{ }^{\circ} \mathrm{C}$. The resulting microstructure is mainly dendritic where most dendrites consist from vanadium carbide eutectics. At the boundaries molybdenum carbide eutectics are localised. The small amount of austenite dendrites was also present. This type of microstructure is quite differrent compared to [11], [16] to [18], [22], [23], [27], [28], [31] and [32], where microstructures containing a large amount of austenite dendrites or a large amount of primary carbides in dependence from the chemical composition of the ledeburitic tool steels are present.

\section{CONCLUSIONS}

The aim of the article is to describe the phase transformations in high alloy cold work tool steel K390 Microclean during slow heating and cooling. These conditions are different compared to those used in production of the alloy steels, but they enable a description of the solidification and phase transitions in quasi-equilibrium conditions.

The microstructure of high alloy cold work tool steel has a dendritic morphology, however, dendrites consists from eutectic colonies based on the vanadium carbides. On the boundaries there are localised molybdenum carbide eutectics. The transformation of austenite to ferrite occurs at about $830{ }^{\circ} \mathrm{C}$. The transition from ferromagnetic to paramagnetic state is about $780^{\circ} \mathrm{C}$.

The knowledge about the quasi-equilibrium phase transformations in high alloy cold work tool steel can help to a better understanding of processes occurring in the material during the heat treatment. The obtained results extend the data obtained by others authors related to ledeburitic tool steels [1], [11], [16], [17], [23], [27], [31] and [32]. The results may be useful for the next thermodynamic analysis of phase transitions using the Thermo-Calc and Dictra software.

\section{ACKNOWLEDGEMENTS}

The authors would like to thank to the financial support provided within the Program for Research and Development for the project Centre for Development and Application of Progressive Diagnostic Methods in the Process of Metallic and Non-metallic Material's Processing, ITMS: 26220120048, co-financed by the
European Foundation for Regional Development. This study was also funded by the Grant Agency of the Ministry of Education of the Slovak Republic and the Slovak Academy of Sciences (VEGA) under the contract No. 1/0339/11.

\section{REFERENCES}

[1] Bratberg, J., Frisk, K. (2004). An experimental and theoretical analysis of the phase equilibria in the Fe-CrV-C system. Metallurgical and Materials Transactions $A$, vol. 35 , no. 12 , p. 3649-3663, DOI:10.1007/s11661004-0271-9.

[2] Jurči, P., Šuštaršič, B., Leskovšek, V. (2010). Fracture characteristics of the Cr-V ledeburitic steel VANADIS 6. Materials and Technology, vol. 44, no. 2, p. 77-84.

[3] Muhič, M., Tušek, F., Klobčar, D. (2010). Analysis of die casting tool material. Strojniški vestnik - Journal of Mechanical Engineering. vol. 56, no. 6, p. 351-356.

[4] Grgač, P., Moravčík, R., Hudáková, M., Béger, M. (2010). Influence of the structural heterogeneity to properties of high alloyed tool steels. 23rd International Conference on Heat Treatment: Proceedings. Jihlava. (In Slovak)

[5] Grgač, P. (1996). The influence of production technologies on strenght and fracture properties of high speed steels. 16 th International Conference on Heat Treatment : Proceedings, Brno. (In Slovak)

[6] ASM International Handbook Committee (1990). ASM Metals Handbook, Volume 01. Properties and Selection: Irons, Steels, and High Performance Aloys. ASM International, Materials Park.

[7] Moravčíková, J., Janáč, A., Moravčík, R. (2006). Compare of tool steels produced by various technology. $7^{\text {th }}$ International conference of Advanced manufacturing operations: Proceedings, Sofia, p. 28-33.

[8] Hoyle, G. (1988). High speed steels. ButterworthHeinemann, Oxford.

[9] ASM International Handbook Committee (1990). ASM Metals Handbook, Volume 07. Powder Metal Technologies and Applications. ASM International, Materials Park.

[10] High performance steels produced by powder metallurgy methods (2010). Böhler Edelstahl information brochure, from http://www.bohleredelstahl.com/english/files/ST035DE_Microclean.pdf, accessed on 2012-08-24.

[11] Boccalini, M., Goldenstein, H. (2001). Solidification of high speed steels. International Materials Reviews, vol. 46, no. 2, p. 92-107, DOI:10.1179/095066001101528411.

[12] Wilmes, S., Kientopf, G. (2002). Carbide dissolution rate and carbide contents in usual high alloyed tool steels at austenitizing temperatures between $900{ }^{\circ} \mathrm{C}$ and $1250{ }^{\circ} \mathrm{C}$. $6^{\text {th }}$ International Tooling Conference, Karlstad, p. 533-541.

[13] Rajasekaran, B., Mauer, G., Vaßen, R., Röttger, A., Weber, S., Theisen, W. (2010). Development of cold 
work tool steel based-MMC coating using HVOF spraying and its HIP densification behavior. Surface \& Coatings Technology, vol. 204, no. 23, p. 3858-3863. DOI:10.1016/j.surfcoat.2010.05.001.

[14] Meurling, F. Melander, A., Tidesten, M., Westin, L. (2001). Influence of carbide and inclusion contents on the fatigue properties of high speed steels and tool steels. International Journal of Fatigue, vol. 23, no. 3, p. 215-224, DOI:10.1016/S0142-1123(00)00087-6.

[15] Cold work tool steel K390 Microclean (2010). Böhler Edelstahl information brochure, from $h t t p: / / w w w$. bohler-edelstahl.com/files/K390DE.pdf, accessed on 2012-04-04.

[16] Behúlová, M., Lipták, M., Grgač, P., Löser, W., Lindenkreuz, H.G. (2009). Comparison of microstructures developed during solidification of undercooled tool steel in levitation and on a substrate. Journal of Physics: Conference Series, vol. 144, no. 1, p. 1-4.

[17] Moravčík, R., Čaplovič, L', Martinkovič, M., Illeková, E., Grgač, P. (1999) Evolution of the microstructure at solidification of Cr-Mo-V tool steel. Technológia 99: $6^{\text {th }}$ International Conference, Proceedings, Bratislava, p. 725-728.

[18] Kusý, M., Grgač, P., Behúlová, M., Výrostková, A., Miglierini, M. (2004). Morphological variants of carbides of solidification origin in the rapidly solidified powder particles of hypereutectic iron alloy. Materials Science and Engineering A, vol. 375-377, p. 599-603, DOI:10.1016/j.msea.2003.10.095.

[19] Boccalini, Jr., M., Sinatora, A. (2002). Microstructure and wear resistance of high speed steels for rollingmill rolls. Proceedings of $6^{\text {th }}$ International Tooling Conference (TOOL), Karlstad, p. 509-524.

[20] Porter, D.A., Easterling, K.E. (1993). Phase transformations in metal and alloys, $2^{\text {nd }}$ ed. Chapman \& Hall, London.

[21] Herring, D. (2009). Tool steel carbides, from: http:// www.vacaero.com/Vacuum-Heat-Treating-with-DanHerring/Vacuum-Heat-Treating-with-Dan-Herring/ tool-steel-carbides.html, accessed on 2012-04-09.

[22] Behúlová, M., Moravčík, R., Kusý, M., Čaplovič, L'., Grgač, P., Stanček, L. (2001). Influence of atomisation on solidification microstructures in the rapidly solidified powder of the Cr-Mo-V tool steel. Materials Science and Engineering A, vol. 304-306, p. 540-543, DOI:10.1016/S0921-5093(00)01511-2.
[23] Moravčík, R. (2009). High alloyed tool steel Habilitation thesis. MTF STU Trnava, Trnava.

[24] Drienovský, M., Čička, R., Janovec, J. (2011). Thermodynamic calculations and thermal analysis of SAC lead-free solders. International Doctoral Seminar 2011 Proceedings. Trnava, p. 100-107.

[25] Drienovský, M., Martinkovič, M., Janovec, J. (2010). Analysis of microstructure and mechanical properties of selected binary and ternary lead-free bulk solders and soldered joints. COST Action MP0602 Advanced Solder Materials for High Temperature Application. 2010 Annual Meeting, International Doctoral Seminar: Proceedings, Trnava, p. 119-125.

[26] Şimşir, C., Gür, C.H. (2010). A simulation of the quenching process for predicting temperature, microstructure and residual stresses. Strojniški vestnik - Journal of Mechanical Engineering, vol. 56, no. 2, p. 93-103.

[27] Homolová, V., Janovec, J., Kusý, M., Moravčík, R., Illeková, E., Grgač, P. (2003). Phase transformations and equilibria in ledeburite type $\mathrm{Ch} 3 \mathrm{~F} 12$ and Ch12MF4 tool alloys. Canadian Metallurgical Quarterly, vol. 42, no. 1, p. 89-96, DOI:10.1179/000844303794535799.

[28] Štefániková, M., Moravčík, R. (2010). Influence of the powder particle size on the microstructure of $\mathrm{Cr}-\mathrm{Mo}-\mathrm{V}$ tool steel compacts produced by hot isostatic pressing. International Doctoral Seminar: Proceedings, Trnava, p. 502-511.

[29] Sales catalog 2012-2013 (2012). International Centre for Diffraction Data, from http://www.icdd.com/ products/pdf2.htm, accessed on 2012-04-12.

[30] Grazulis, S., Chateigner, D., Downs, R. T., Yokochi, A. T., Quiros, M., Lutterotti, L., Manakova, E., Butkus, J., Moeck, P. \& Le Bail, A. (2009). Crystallography Open Database - an open-access collection of crystal structures. Journal of Applied Crystallography, vol. 42, p. 726-729, DOI:10.1107/S0021889809016690.

[31] Behulova, M., Grgac, P., Kabat, E. (1996) In: Duhaj P., Mrafko, P., Svec, P. (eds.). Proceeding of the 9th International Conference on the Rapidly Quenched and Metastable Materials, Bratislava, Elsevier, p. 10.

[32] Grgač, P., Kusý, M., Behúlová, M. (2010). Microstructures developed during rapid solidification of tool steels of ledeburite type. COMEC, VI. Proceeding of the International Scientific Conference of Mechanical Engineering. Las Villas. 